\title{
PRIVATE BANKING AND ASSET MANAGEMENT PRACTICES IN TURKEY AND INTERNATIONAL SCOPE
}

\author{
DOI: 10.17261/Pressacademia.2021.1522 \\ PAP- V.14-2021(48)-p.165-166
}

\section{Canan Musluoglu}

Istanbul Commerce University, Finance Institute, Department of Banking, Istanbul, Turkey. canan.musluoglu@hotmail.com, ORCID: 0000-0001-9890-4443

To cite this document

Musluoglu, C., (2021).Private banking and asset management practices in Turkey and international scope. PressAcademia Procedia (PAP), 14, 165-166.

Permanent link to this document: $h$ ttp://doi.org/10.17261/Pressacademia.2021.1522

Copyright: Published by PressAcademia and limited licensed re-use rights only.

\begin{abstract}
Purpose - Within the changing world conditions high net worth people aim to keep and increase their assets by taking actions, having expectations and demands and taking all of these into consideration this article tries to verify the bank's important position.

Methodology- In parallel with the financial expectations and targets of these people; widened investment \& asset allocation \& short-long term investment alternatives are very important facts to have the client loyalty. The changes in the number of clients \& their assets during last few years; making national \& international comparisons, shows us the ideal service models both in the benefit of the bank and the client. Findings - The desire of wealthy individuals to protect and raise their assets has not changed since the first private bank was established. Along with the perception of risk, asset allocation, getting the right service from the right place, and providing differentiated personalized products \& services have changed greatly. Although the number of high-wealth customers is not very high in Turkey, the rate of increase includes a noticeable difference compared to other countries. Today; the number of high-net worth individuals around the world is increasing every year. It is possible to monitor this situation from the increase in the number of high-net worth people in Europe between $2013-2019$. As the amount of thei assets increases, the bank client's expectations begin to rise. Expectations are not only in the field of financial support, but also triggered the expectation of more personalized service and more special products. This expectation has brought competition with it, and it has emerged as a product and service diversity in the sector.The most basic feature is gaining customer trust. This brings with it the loyalty of the person to the institution and being the main factor that determines the preferences in a challenging market that can be named as thrust chain.It is of great importance in terms of customer satisfaction that the financial information given to the customers is complete and diverse, because it should always be remembered that the final decision is made by the customer. When we look at the examples of preferences of the customer representatives, it has been observed that they may have preferences other than the ones they suggest in their institutions. From this point of view, it is indisputable that the financial customer should obtain all the information and that he/she makes his/her own investment decisions within this framework.Two types of wealth are noteworthy. The first is those who are wealthy from the family, and the second is those who acquire wealth after a certain education and work experience. To distinguish these customer types from each other; can provide great convenience for a bank.

Conclusion - Providing a more technologically advanced environment in the services offered to customers, will also bring about being more effective in international markets. It is observed that the information flow to customers about international markets can be as fast and rapid as in the country, and the completeness of all financial or non-financial product/service information, is the feature that can make the most important difference. It is not always predictable how customer expectations and preferences will be shaped. For this reason, if a bank acts on the basis that each customer can deal with all products \& services, it will be more satisfactory and profitable for both the customer and the bank. Private Banking and Wealth Management, which is developing in our country; will be able to achieve success not only in our country but also in the international arena, especially with the right segmentation, the right product presentation to the right customer, the expansion of the privacy principles and other product / service scale, and technological developments at a level that will meet the expectations.
\end{abstract}

Keywords: private banking, asset management, bank client, high net worth, ultra high net worth JEL Codes: G11, G20, G24

\section{TÜRKIYE’DE VE DÜNYADA, ÖZEL BANKACILIK VE VARLIK YÖNETIMI UYGULAMALARI}

\section{ÖZET}

Amaç- Ülkemizde ve dünyada Özel Bankacılık ve Varlık Yönetimi Uygulamaları konulu çalışmada, değişen dünya düzeni içerisinde yüksek finansal varlığa sahip kişilerin, varlıklarını korumak/arttırmak için aldıkları aksiyonlar, beklentileri \& tercihleri ve bu unsurlar içerisinde bankaların önemli yeri irdelenmektedir.

Yöntem-Yüksek finansal varlığa sahip kişilerin finansal beklentileri ve hedefleri paralelinde, geniş yatırım seçenekleri ile risk gruplarına bağlı olarak varlık alokasyon alternatifleri önerilmesi, orta ve uzun vade yatırım yaklaşımları alternatifleri sunulması, müşteri sadakati açısından büyük önem taşımaktadır. Bu müşterilerin Türkiye \& uluslararası ortamda adetsel \& varlık tutarı olarak zaman içerisindeki gelişimi ve bu 
gelişim çerçevesinde, müşteri taleplerindeki değişim de göz önünde bulundurularak, nasıl bir hizmet modeli ile hem müşteri hem de banka açısından maksimum fayda sağlayabileceği konularında da analizler yapılarak, mevcut hizmet modelleri değerlendirilecektir.

Bulgular - Varlığı yüksek bireylerin varlıklarını koruma ve yükseltme istekleri, ilk özel bankayı kuruluşundan bu yana değişmemiştir. Risk algısı ile beraber varlık alokasyonu, doğru hizmeti doğru yerden alma ve farklılaştırılmış kişiye özel ürün \& hizmetlerin sağlanması, büyük değişim göstermiştir. Yüksek varlıklı müşteri adedi Türkiye'de çok fazla olmamakla beraber, artış hızı diğer ülkelere göre gözle görülür bir fark içermektedir. Günümüzde; dünyadaki yüksek varlıklı bireysel kişilerin adetleri her yıl artmaktadır. Bu durumu Avrupa'da 2013-2019 yılları arasında yüksek varlıklı kişilerin adedindeki artıştan izlemek mümkündür. Banka müşterilerinin varlık tutarı arttıkça, beklentileri de yükselmeye başlamaktadır. Beklentiler sadece finansal destek alanında olmayıp, aynı zamanda daha kişiselleştirilmiş hizmet ve daha özel ürünler sunulması beklentisini tetiklemiştir. Bu beklenti beraberinde rekabeti getirmiş, rekabette, sektörde ürün ve hizmet çeşitliliği olarak ortaya çıkmıştır. Burada en temel özellik müşteri güveninin kazanılmasıdır. Bu beraberinde kişinin kuruma olan bağlılı̆ını getirmekte ve zorlu bir pazarda tercihleri belirleyen ana faktör olan güven zinciri karşımıza çıkmaktadır. Müşterilere verilen finansal bilgilerin tam ve çeşitli olması, müşteri memnuniyeti açısından büyük önem arz etmektedir. Çünkü her zaman son kararın yine müşteri tarafından verildiği unutulmamalıdır. Müşteri temsilcilerinin kendi tercihlerine baktığımızda, kurumlarında önerdiklerinin dışında tercihlerinin olabildiği gözlemlenmiştir. Buradan yola çıkarak finansal müşterinin tüm bilgileri edinmesi gerektiği ve bu çerçevede kendi yatırım kararlarını kendisinin aldığı tartışma götürmezdir. İki çeşit varlık biçimi dikkat çekicidir. Birincisi aileden zengin olan kişiler, ikincisi ise belirli bir eğitim ve iş tecrübesi sonrasında varlık edinenler. Bu müşteri tiplerini birbirinden ayırma; bir banka için büyük kolaylık sağlayabilecektir.

Sonuç - Müşterilere sunulan hizmetlerde özellikle teknolojik olarak daha gelişmiş bir ortamın sağlanması, uluslararası piyasalara da daha etkin olunmasını beraberinde getirecektir. Müşterilere uluslararası piyasalar ile ilgili bilgi akışının da ülke içerisindeki gibi hızlı ve seri olabilmesi, finansal olan veya olmayan, tüm ürün/hizmet bilgilerinin eksiksiz olması en fazla fark yaratabilecek özellik olarak gözlemlenmektedir. Müşteri beklenti ve tercihlerinin nasıl şekilleneceği her zaman öngörülemez. Bu nedenle bir bankanın, her müşterinin tüm ürünler \& hizmetler ile ilgilenebileceğinden yola çıkarak hareket etmesi, yine hem müşteri hem banka açısından daha memnun edici ve karlı olabilecektir. Ülkemizde gelişmekte olan Özel Bankacılık ve Varlık Yönetimi; özellikle doğru segmentasyon, doğru müşteriye doğru ürün sunumu, gizlilik esasları ve diğer ürün / hizmet skalasının genişletilmesi ve beklentiyi karşılayacak düzeyde teknolojik gelişmeler ile başarı yakalayabilecektir.

Anahtar Kelimeler: Özel bankacılık, varlık yönetimi, banka müşterisi, yüksek varlıklı, ultra yüksek varlıklı JEL Kodları: G11, G20, G24

\section{REFERENCES}

Chorafas, D.N. (2006). Private Banking Defined Wealth Management: Private Banking, Investment Decisions, and Structured Financial Products. 1(3)

https://books.google.com.tr/books?hl=tr\&lr=\&id=uQOYqEqliBcC\&oi=fnd\&pg=PP1\&dq=Wealth+Management:+Private+Banking,+lnvestme nt+Decisions, +and+Structured+Financial+Products\&ots=AiOGobiiCB\&sig=YF5SJOK6zLSha6h4e0-

vm1d9CWA\&redir esc=y\#v=onepage \&q=Wealth\%20Management\%3A\%20Private\%20Banking\%2C\%20Investment\%20Decisions\%2C\%20an d\%20Structured\%20Financial\%20Products\&f=false

Ross S. M. \& Dufey, G. (2009). Private Banking in Asia- A Survey. 10-11. https://papers.ssrn.com/sol3/papers.cfm?abstract id=1463261 adresinden alınmıştır.

Beaverstock, J. V. \& Hall, S. \& Wainwright, T.(2011). Servicing The Super Rich : New Financial Elites and the Rise Of The Private Wealth Management Retail Ecology, 8. https://www.tandfonline.com/doi/full/10.1080/00343404.2011.587795?scroll=top\&needAccess=true

Schueffel, P. (2019). WealthTech: Wealth and Asset Management in the FinTech Age. Information Age Publishing., 57.

Wilson, E. (2020). Santander's private bankers profit from a year of hard toil .Euromoney, 1.

Statista Araştırma Departmanı, (2020). Number of high net worth individuals worldwide from 2010 to 2019 , by region. Statistica https://www.statista.com/statistics/263488/millionaires-worldwide-by-region/

Duffin, E. (2020). Population of high net worth individuals (HNWI) in Europe from 2013 to 2019, bycountry. Satatistica https://www.statista.com/statistics/424981/europe-high-net-worth-individuals

Danon, M. ve Teker, S. (2020). Wealth management trends in the world. Global Business Research Congress. 158. https://dergipark.org.tr/tr/download/article-file/1222226

Knight, F. (2017) .The Weath Report New World Wealth Notes. 67. https://chriskalin.com/wp-content/uploads/2018/07/the-wealth-report2017.pdf/Databank

Sbard, P.M. \& Omarını, A. (2005). Private Banking In Europe - Getting Clients \& Keeping Them!. İdeas Electronic Journal, 9-16. https://citeseerx.ist.psu.edu/viewdoc/download?doi=10.1.1.467.1781\&rep=rep1\&type=pdf

Ting, H. (2017). Factors affecting wealth management services: from investors' and advisors' perspectives. The Journal of Wealth Management, 22-23. https://iwm.pm-research.com/content/20/1/17.full 